\title{
Proheparin-Binding EGF-Like Growth
}

\section{Factor}

National Cancer Institute

\section{Source}

National Cancer Institute. Proheparin-Binding EGF-Like Growth Factor. NCI Thesaurus.

Code C118380.

Proheparin-binding EGF-like growth factor (208 aa, $23 \mathrm{kDa}$ ) is encoded by the human HBEGF gene. This protein plays a role in both heart valve formation and mitogenesis for fibroblasts and smooth muscle cells. 